\title{
Erratum to: A year for JCCS editorial changes and CCN3 KO mice at ICCNS
}

\author{
Bernard Perbal $^{1,2}$
}

Published online: 29 July 2016

(C) The International CCN Society 2016

Erratum to: J. Cell Commun. Signal. (2016) 10:1-2

DOI 10.1007/s12079-016-0318-x

The original version of this article unfortunately contained a mistake in the title. The correct article title is presented above.

The online version of the original article can be found at http://dx.doi. org/10.1007/s12079-016-0318-x.

Bernard Perbal

bperbal@gmail.com

1 Sources et Méthodologie du Droit Economique.

GREDEG-CREDECO CNRS UMR 7321, Université de

Nice-Sophia Antipolis, Nice, France

2 International CCN Society, Nice, France 